\title{
ZWALCZANIE NIEUCZCIWEJ KONKURENCJI

\author{
ROZWAŻANIA NA TLE ZBIEGU PRZEPISÓW PRAWA CYWILNEGO \\ I KARNEGO
}

Na mocy postanowień Konstytucji RP podstawę ustroju gospodarczego w naszym kraju stanowi społeczna gospodarka rynkowa, która oparta jest w szczególności na zasadzie wolności działalności gospodarczej ${ }^{1}$. Wyrazem tego jest przysługujące każdemu przedsiębiorcy prawo do zasadniczo nieskrępowanego zakładania i prowadzenia takiej działalności ${ }^{2}$. Z wolnością obrotu gospodarczego wiązane sa także dalsze reguły, spośród których najistotniejszymi wydają się zasady prawnej równości przedsiębiorców, poszanowania dobrych obyczajów oraz słusznych interesów konsumentów ${ }^{3}$. Za „logiczną ich konsekwencję" uznaje się zaś zasadę konkurencji ${ }^{4}$, której rozwinięcie znajduje swoje odzwierciedlenie $\mathrm{w}$ przepisach wielu aktów prawnych, zapewniajacych prawidłowe funkcjonowanie obrotu gospodarczego. Szczególne miejsce wśród nich przypada ustawie z 16 kwietnia 1993 r. o zwalczaniu nieuczciwej konkurencji ${ }^{5}$. Jej specyfika przejawia się przede wszystkim w zakresie normowanej w niej materii, której istotę stanowią czyny nieuczciwej konkurencji. W myśl art. 3 powołanej ustawy i zawartej $\mathrm{w}$ tym artykule klauzuli generalnej ${ }^{6}$, czynami takimi są działania sprzeczne z prawem lub dobrymi obyczajami, jeżeli zagrażaja one innemu przedsiębiorcy lub klientowi lub naruszają ich interes. Jako regulacja należąca do sfery prawa prywatnego ${ }^{7}$, zaliczana jest ona również do wyodrębnionej dziedziny - prawa konkurencji ${ }^{8}$. W tym względzie „,trzon” tej ustawy stanowią art. 1-22 (w tym zwłaszcza art. 5-17d, w których opisano

${ }^{1}$ Por. art. 20 Konstytucji RP, a także: P. Winczorek, Komentarz do Konstytucji Rzeczypospolitej Polskiej z dnia 2 kwietnia 1997 r., Warszawa 2000, s. 32-33.

${ }^{2}$ Od zasady wolności gospodarczej ustawa może przewidywać wyjątki. Takim wyjątkiem będzie w szczególności wymóg uzyskania koncesji albo zezwolenia na prowadzenie danego rodzaju działalności gospodarczej - por. zwłaszcza art. 6 oraz art. 46-75 ustawy z 2 lipca 2004 r. o swobodzie działalności gospodarczej (tekst jedn.: Dz. U. 2010, Nr 220, poz. 1447 ze zm.), a także: C. Kosikowski, Ustawa o swobodzie działalności gospodarczej. Komentarz, wyd. 6, Warszawa 2011, s. 60-71 i 223 i n.

${ }^{3}$ Por. J. Skorupka, Prawo karne gospodarcze. Zarys wyktadu, Warszawa 2007, s. 34-36.

${ }^{4}$ K. Kruczalak, Prawo handlowe. Zarys wyktadu, Gdańsk 1992, s. 50. Podobnie: T. M. Knypl, Zwalczanie nieuczciwej konkurencji w Polsce i Europie, Sopot 1994, s. 13-15.

${ }^{5}$ Tekst jedn.: Dz. U. 2003, Nr 153, poz. 1503 (dalej jako: u.z.n.k.).

${ }^{6}$ Por. J. Szwaja, w: idem (red.), Ustawa o zwalczaniu nieuczciwej konkurencji. Komentarz, wyd. 2, Warszawa 2006, s. 133-141. Podobnie: M. Zdyb, w: M. Sieradzka, M. Zdyb (red.), Ustawa o zwalczaniu nieuczciwej konkurencji. Komentarz, Warszawa 2011, s. 86.

7 Por. M. Kępiński, Problemy ogólne nowej ustawy o zwalczaniu nieuczciwej konkurencji, „Ruch Prawniczy, Ekonomiczny i Socjologiczny" 1994, z. 2, s. 2.

${ }^{8}$ Por. J. Szwaja, w: idem (red.), op. cit., s. 64. 
poszczególne czyny nieuczciwej konkurencji). Poza obszarem cywilnoprawnym u.z.n.k. zawiera jednak również w art. 23-27 przepisy karne, uznawane za część prawa karnego gospodarczego ${ }^{9}$. Jego przepisy mają z kolei służyć zapewnieniu ochrony nie tylko ,gospodarczych stosunków cechujących się nadrzędną rolą państwa", ale przede wszystkim mają one za zadanie stać na straży ustrojowych zasad gospodarczych i obowiązujących instytucji prawnych ${ }^{10}$. Już z samego więc założenia u.z.n.k. przewiduje szeroko ujęta ochronę zarówno podmiotów uczestniczących $\mathrm{w}$ obrocie, jak i interesu publicznego, wyznaczoną przepisami prawa cywilnego i karnego. Na styku tych uregulowań nierzadko dochodzi do braku spójności czy wręcz kolizji. Chociaż taki stan rzeczy może się wydawać naturalny dlatego, że chodzi o przepisy zakorzenione w różnych gałęziach prawa, a co za tym idzie, zawierające odmienne w swoich funkcjach i celach unormowania, oparte na różnej metodzie regulacji, to jednak głębsza ich analiza może wskazywać, że sytuacja taka nie zawsze zdaje się działaniem zamierzonym przez ustawodawcę. Za takim podejściem przemawia przede wszystkim okoliczność, że w wypadku wspomnianej ustawy chodzi wprawdzie o przepisy należące do różnych dziedzin prawa, jednak zawarte w jednym i tym samym akcie prawnym. Warto zatem przyjrzeć się bliższej pewnym regulacjom ustawy o zwalczaniu nieuczciwej konkurencji i przeanalizować je pod kątem braku wzajemnej spójności zawartych w niej przepisów cywilnych i karnych.

W pierwszej kolejności wypada zatem ustalić, w jakich relacjach pozostaja powyższe unormowania, temu zaś najlepiej będzie służyć wzajemne ich porównanie. Na tym tle moga bowiem pojawiać się wątpliwości związane między innymi z potrzebą wyznaczenia zakresu, jaki obejmują występki i wykroczenia określone w ustawie o zwalczaniu nieuczciwej konkurencji. Wspomniana ustawa czyni przy tym przedmiotem regulacji zachowania nieuczciwej konkurencji ukształtowane na wzór deliktów cywilnoprawnych ${ }^{11}$, co natomiast może rodzić pytanie o to, czy czyny karalne uregulowane w jej art. 23-27 będą wymagały potraktowania w sposób zawężający określonych w nich czynności sprawczych. Innymi słowy, czy za czynności takie będą mogły zostać uznane jedynie zachowania odpowiadające opisowi nazwanych czynów nieuczciwej konkurencji, czy może za takowe będzie mogło zostać uznane każde zachowanie, jeżeli tylko będzie ono spełniało znamiona wyrażone w opisie typu czynu zabronionego zawartego w przepisie karnym u.z.n.k., i to bez względu na to, czy będzie ono „odpowiednim” czynem nieuczciwej konkurencji? Konsekwencją tego drugiego podejścia będzie rezygnacja z potrzeby uprzedniego ustalania zakresu regulacji cywilnoprawnej. Kwestia jest tym bardziej doniosła, że art. 5-17d ustawy z 16 kwietnia 1993 r., precyzując, na czym polegaja opisane w nich czyny nieuczciwej konkurencji, wskazują nierzadko na wyjątki, które wyłączaja możliwość uznania zachowania za taki czyn.

Najlepszym tego przykładem może być art. 11 ust. 1 u.z.n.k. i określony w nim czyn nieuczciwej konkurencji polegający na bezprawnym ujawnieniu

\footnotetext{
${ }^{9}$ R. Zawłocki, Prawo karne gospodarcze, Warszawa 2007, s. 62-64, a także: J. Skorupka, op. cit., s. $17-18$.

${ }^{10}$ S. Żółtek, Prawo karne gospodarcze w aspekcie zasady subsydiarności, Warszawa 2009, s. 39.

${ }^{11}$ Por. J. Szwaja, w: idem (red.), op. cit., s. 61.
} 
tajemnicy przedsiębiorstwa, czyli na „,przekazaniu, ujawnieniu lub wykorzystaniu cudzych informacji stanowiących tajemnicę przedsiębiorstwa albo ich nabyciu od osoby nieuprawnionej, jeżeli zagraża lub narusza interes przedsiębiorcy". Natomiast w ust. 3 tego artykułu zawiera wyłączenie, które nie pozwala uznać za wspomniany czyn sytuacji, gdy dana osoba nabyła w dobrej wierze i na podstawie odpłatnej czynności prawnej informacje stanowiące tajemnicę przedsiębiorstwa ${ }^{12}$. Odpowiadający temu deliktowi występek został uregulowany $\mathrm{w}$ art. 23 przedmiotowej ustawy. Ten $\mathrm{z}$ kolei nakazuje uznawać za czyn zabroniony każdy wypadek ujawnienia innej osobie lub wykorzystania we własnej działalności gospodarczej informacji stanowiącej tajemnicę przedsiębiorstwa, jeżeli sprawca postąpił wbrew ciążącemu na nim obowiązkowi w stosunku do przedsiębiorcy i wyrządził mu przez to poważna szkodę. Przyjęcie, że przytoczone przestępstwo winno być czynem nieuczciwej konkurencji, oznaczałoby, że poza zakresem art. 23 u.z.n.k. pozostaje sytuacja, w której zobowiązanie jego sprawcy do nieujawniania (odpowiednio - niewykorzystywania we własnej działalności) informacji stanowiącej tajemnicę przedsiębiorstwa wynikało $\mathrm{z}$ zawarcia odpłatnej umowy, a przy tym, jako jej nabywca, wykazał się on dobra wiarą. W tym miejscu można podać przykład, gdy dana osoba (potencjalny sprawca przestępstwa określonego w art. 23 u.z.n.k.), jako franczyzobiorca nabywa odpłatnie informację stanowiąca poufne know-how firmy od osoby trzeciej ${ }^{13}$, podającej się za uprawniona do przekazania mu takich informacji, podczas gdy faktycznie zbywca tej informacji nie był uprawniony do jej udzielenia. W takim wypadku wykorzystanie przez nabywcę we własnej działalności takiej informacji winno przynajmniej teoretycznie - pozostawać poza zakresem regulacji wynikającej z ustawy o zwalczaniu nieuczciwej konkurencji (przewidzianej zarówno w przepisach cywilnych, skoro czyn taki nie będzie stanowił czynu nieuczciwej konkurencji z powodu wyłączenia, o którym mowa w ust. 3 art. 11 u.z.n.k., jak i w przepisach karnych, gdyż nie jest on takim czynem $\mathrm{w}$ rozumieniu wspomnianej ustawy). To zaś prowadziłoby do pozbawienia ochrony przedsiębiorcy, którego tajemnicę wynikającą z prowadzonej przez niego działalności gospodarczej ujawniono (wykorzystano ja do działalności innego podmiotu). Wydaje się, że takie podejście pozostawałoby sprzeczne już z samego tylko założenia z celami powołanej ustawy z 16 kwietnia $1993 \mathrm{r}$.

W tym miejscu można posłużyć się ilustrującym tę problematykę przykładem: przedstawiciel przedsiębiorstwa X - osoba A, której wygasło pełnomocnictwo do reprezentowania firmy, odpłatnie zbywa informacje dotyczące nowoczesnych rozwiązań w technologii informatycznej innej osobie (nabywcy B). Podmiot A działa przy tym z oczywistym zamiarem przysporzenia

${ }^{12}$ W literaturze przedmiotu podważono zasadność uzależniania wyłączenia zawartego od odpłatnego charakteru czynności prawnej i uznanie, za wystarczające, istnienie dobrej wiary u nabywcy - por. T. M. Knypl, op. cit., s. 126.

${ }^{13} \mathrm{~W}$ kwestii pojęcia tajemnicy przedsiębiorstwa a jego know-how - por. A. Michalak, Ochrona tajemnicy przedsiębiorstwa. Zagadnienia cywilnoprawne, Kraków 2006, s. 146-148; a także: C. Kosikowski, T. Ławicki, Ochrona prawna konkurencji $i$ zwalczanie praktyk monopolistycznych, Warszawa 1994, s. 189. 
przedsiębiorcy X, którego „reprezentuje”, korzyści pochodzących z tytułu odpłatnego zbycia poufnych informacji. Z kolei nabywca (B) kupuje te informacje $\mathrm{z}$ zamiarem wykorzystania ich we własnej działalności gospodarczej, a przy tym będąc przekonany, że uzyskuje on je w sposób legalny od uprawnionego przedstawiciela firmy $\mathrm{X}$, pozostaje on nabywca $\mathrm{w}$ dobrej wierze. Faktycznie jednak czynność prawna prowadząca do przysporzenia była niezupełna (negotium claudicans), a walor $\mathrm{w}$ pełni zgodnej z przepisami prawa cywilnego (ważność) uzyskałaby ona dopiero w razie jej potwierdzenia przez mocodawcę (w podanym przykładzie właściciela firmy $\mathrm{X})^{14}$. W sytuacji gdyby takiego potwierdzenia zabrakło, nabywca B przestaje być osobą w dobrej wierze. Jeżeli jednak przyjąć, że istnienie dobrej wiary przy nabyciu informacji stanowiącej tajemnicę przedsiębiorstwa bada się w dacie nabycia takiej wiadomości, a późniejsza zmiana stanu świadomości nie ma znaczenia prawnego ${ }^{15}$, to odpowiedzialność takiej osoby może się kształtować odmiennie na gruncie reżimu cywilnego i karnego. W pierwszym wypadku wyłączone będzie przyjęcie, że nabywca dopuścił się względem przedsiębiorcy X czynu nieuczciwej konkurencji, polegającego na wykorzystaniu we własnej działalności informacji stanowiących tajemnicę jego przedsiębiorstwa, na zasadzie wyjątku, o którym mowa w art. 11 ust. 3 u.z.n.k. Stosownie zaś do tego przepisu, w takiej sytuacji sąd może jedynie zobowiązać nabywcę do zapłaty stosownego wynagrodzenia za korzystanie z takich informacji (nie dłużej niż do ustania stanu tajemnicy). Natomiast w odniesieniu do odpowiedzialności karnej nie można „z góry” przesądzić o braku możliwości jej ponoszenia przez nabywcę, tylko z tego powodu, że jego zachowanie nie stanowiło czynu nieuczciwej konkurencji ${ }^{16}$. Prawo karne nakazywałoby bowiem w takim wypadku ustalić raczej, czy nabywca przewidywał, że może wejść $\mathrm{w}$ posiadanie takich informacji wbrew woli przedsiębiorcy X, i czy towarzyszyła temu chociażby dorozumiana akceptacja takiego stanu rzeczy (na przykład dostrzegł on wyraźnie rzucająca się w oczy datę pełnomocnictwa, która wskazywała na jego wygaśnięcie). Wówczas ze względu na istniejący u sprawcy (B) zamiar ewentualny popełnienia czynu zabronionego opisanego w art. 23 u.z.n.k. ${ }^{17}$ nie byłoby przeszkód do pociągnięcia go do odpowiedzialności za występek, o którym mowa w art. 23 ust. 2 u.z.n.k. (za wykorzystanie we własnej działalności gospodarczej uzyskanych bezprawnie informacji stanowiących tajemnicę przedsiębiorstwa). Dla odmiany, gdyby z okoliczności transakcji wynikało, iż B miał podstawy sądzić, że A jest pełnoprawnym pełnomocnikiem przedsiębiorcy $\mathrm{X}$, to wobec braku po stronie B zamiaru (a zatem i umyślności), nie doszłoby do wyczerpania znamion wspomnianego przestępstwa.

\footnotetext{
14 Por. art. 103 \& 1 k.c.

15 Tak: E. Nowińska, M. du Vall, Komentarz do ustawy o zwalczaniu nieuczciwej konkurencji, wyd. 5, Warszawa 2010, s. 400.

${ }^{16}$ Odmiennie: E. Nowińska, M. du Vall, op. cit., s. 401. Autorzy wyłączają możliwości zakwalifikowania zachowania jako karalnego w wypadku, o którym mowa w art. 11 ust. 3 u.z.n.k.

${ }^{17}$ Zgodnie z art. 9 k.k. czyn zabroniony popełniony jest umyślnie, jeżeli sprawca ma zamiar jego popełnienia, to jest chce go popełnić albo przewidując możliwość jego popełnienia, na to się godzi. Z kolei art. 23 u.z.n.k. dla realizacji znamion określonego w nim przestępstwa wymaga, aby zachowanie sprawcy cechowała właśnie umyślność.
} 
$\mathrm{Z}$ tego powodu nie do przyjęcia wydaje się uzasadnienie, aby $\mathrm{w}$ takiej sytuacji: „Istnienie dobrej wiary wyłączało stan świadomości, tj. realizację znamienia strony podmiotowej czynu zabronionego"18. Z punktu widzenia prawa karnego o istnieniu zamiaru przesądzają bowiem dwa elementy (zwane dwoma stronami zamiaru): element intelektualny, który sprowadza się najogólniej rzecz ujmując - do świadomości sprawcy oraz element wolicjonalny, związany z chęcią (jak przy zamiarze bezpośrednim), albo jej brakiem, ale przy istniejącym ,godzeniu” się na realizację znamion typu czynu zabronionego (zamiar ewentualny) ${ }^{19}$. Sama świadomość nie jest zatem wystarczająca dla uznania, że sprawca popełnił czyn zabroniony umyślnie.

$\mathrm{W}$ odniesieniu do podnoszonej tutaj problematyki wypada również zauważyć, że delikt cywilny wskazany w art. 11 u.z.n.k. został ujęty szerzej od strony znamion czynnościowych niż „odpowiadający” mu występek z art. $23^{20}$. Czyn nieuczciwej konkurencji polega bowiem na przekazaniu, ujawnieniu lub wykorzystaniu (jakimkolwiek) cudzych informacji, stanowiących tajemnicę przedsiębiorstwa, względnie na ich nabyciu od osoby nieuprawnionej. Poza tym do jego popełnienia wystarczającym jest, aby zachowanie takie chociażby tylko stworzyło zagrożenie dla interesów przedsiębiorcy, którego tajemnicę bezprawnie ujawnia dana osoba ${ }^{21}$. Dla odmiany, typy czynów zabronionych określone $\mathrm{w}$ art. 23 ustawy czyni karalnym wyłącznie ujawnienie, bądź wykorzystanie - i to tylko we własnej działalności, informacji stanowiących tajemnicę przedsiębiorstwa ${ }^{22}$. Przekazanie ich lub nabycie (!) pozostają więc poza zakresem regulacji prawnokarnej. Już taki sposób ujęcia znamion czynnościowych może dowodzić, że intencją ustawodawcy była penalizacja dokładnie tych (i tylko tych) czynów, które opisał on w odpowiednim przepisie karnym i których znamiona - jako czynów karalnych, sprawca może zrealizować swoim zachowaniem. Nie wymaga on, aby występek taki zastał uznany uprzednio za odpowiedni czyn nieuczciwej konkurencji, ani nie wyłącza stosowania przepisu karnego tylko dlatego, że zachowanie sprawcy stanowi wyjątek, niepozwalający na uznanie go za taki czyn ${ }^{23}$.

W piśmiennictwie wyrażono również - co do zasady trafny - pogląd, że wyłącznie najbardziej niebezpieczne społecznie czyny nieuczciwej konkurencji stanowia przedmiot represji karnej ${ }^{24}$. Poza zmianami związanymi z odejściem od pojęcia „społecznego niebezpieczeństwa” i zastąpienia go

${ }^{18}$ E. Czarny-Drożdżejko, Karna ochrona uczciwości konkurencji, „Czasopismo Prawa Karnego i Nauk Penalnych" 1999, nr 2, s. 8.

19 Por. A. Zoll, w: idem (red.), Kodeks karny. Komentarz. Część ogólna, t. 1: Komentarz do art. 1-116 k.k., wyd. 4, Warszawa 2012, s. 141-152.

${ }^{20}$ E. Nowińska, M. du Vall, op. cit., s. 400.

${ }^{21}$ Por. A. Michalak, op. cit., s. 194.

${ }^{22}$ M. Mozgawa, Zwalczanie nieuczciwej konkurencji środkami prawa karnego, Gdańsk 1997, s. 40.

${ }^{23}$ Odmiennie: E. Nowińska, M. du Vall, op. cit., s. 398-399.

${ }^{24}$ L. Górnicki, Nieuczciwa konkurencja $w$ szczególności przez wprowadzajace $w$ bład oznaczenie towarów lub ustug, $i$ środki ochrony $w$ prawie polskim, Wrocław 1997, s. 120; podobnie: J. Raglewski, Wybrane problemy interpretacyjne przepisów karnych ustawy o zwalczaniu nieuczciwej konkurencji z 1993 r., „Zeszyty Naukowe Uniwersytetu Jagiellońskiego. Prace z Prawa Własności Intelektualnej” 2010, z. 109 , s. 124. 
„,społeczną szkodliwością" czynu ${ }^{25}$, warto wskazać jednak, że w aktualnym stanie prawnym reguła ta doznaje wyjątku. W tym miejscu należy przywołać czyn nieuczciwej konkurencji określony w art. 15a ustawy z 16 kwietnia 1993 r. ${ }^{26}$ Czyn ten polega na przekupstwie osoby pełniącej funkcję publiczną, za która ustawa ta nakazuje uznawać zachowanie o znamionach określonych w art. 229 k.k. Odnośny przepis penalizuje przestępstwo korupcji czynnej (przekupstwo). Ma ono niejako ,odwrotny” charakter do przestępstwa łapownictwa (korupcji biernej) określonego w art. $228^{27}$. Odpowiedzialność za nie może ponosić każda osoba, która udziela lub obiecuje udzielić korzyści majątkowej ( $\$ 1$ art. 229 k.k.). Jest to więc przestępstwo powszechne. Znamiona określające podmiot powyższego przestępstwa modyfikuje jednak art. 15a u.z.n.k., zawężając go do osoby fizycznej będącej przedsiębiorcą bądź działającej na rzecz przedsiębiorcy w ramach uprawnienia do jego reprezentowania albo podejmowania $\mathrm{w}$ jego imieniu decyzji lub wykonywania nad nim kontroli, względnie działającej na rzecz przedsiębiorcy, za zgodą osoby, o której mowa powyżej. Tym samym czyn nieuczciwej konkurencji - w przeciwieństwie do przestępstwa, o którym mowa w art. 229 k.k. - jest deliktem o charakterze indywidualnym. Oznacza to, iż dopuścić się go może jedynie osoba wskazana $\mathrm{w}$ art. 15a u.z.n.k. Tak sformułowany przepis - w zamierzeniu ustawodawcy miał dostosować nasze krajowe unormowania do międzynarodowych, w tym zwłaszcza wynikających z postanowień Konwencji o zwalczaniu przekupstwa zagranicznych funkcjonariuszy publicznych, podpisanej w imieniu Rządu Polskiego w Paryżu 17 grudnia 1997 r. i ratyfikowanej przez Sejm 22 stycznia 2000 r. ${ }^{28}$ Konwencja ta w art. 3 ust. 1 i 3 nakłada na nasze państwo obowiązek uregulowania kwestii ponoszenia odpowiedzialności za przekupstwo zagranicznego funkcjonariusza nie tylko przez osoby fizyczne, ale i prawne ${ }^{29}$. W obecnym stanie prawnym zasady ponoszenia odpowiedzialności karnej przez te ostatnie reguluje ustawa z 28 października 2002 r. o odpowiedzialności podmiotów zbiorowych ${ }^{30}$, która w art. 16 ust. 1 pkt 3 lit. a) stwarza podstawy do jej ponoszenia przez podmiot zbiorowy między innymi za przestępstwo

\footnotetext{
${ }^{25}$ Element ,społecznego niebezpieczeństwa” uzasadniał dualistyczną ocenę zachowania sprawcy: z jednej strony, była to ocena ujmowana abstrakcyjnie i relatywizowana do sfery ustawodawczej (oceny takiej dokonywał prawodawca na płaszczyźnie przepisu karnego, wskazując, które z zachowań powinny być kryminalizowane) oraz - z drugiej - powierzając ocenę zachowania konkretnego sprawcy organowi stosującemu prawo, który przesądzał, czy penalizowane zachowanie w danym wypadku nosiło cechę „,społecznie niebezpiecznego". Więcej na ten temat por. R. Zawłocki, Pojecie $i$ funkcje spotecznej szkodliwości czynu w prawie karnym, Warszawa 2007, s. 63-64, a także: A. Zoll, Materialne określenie przestepstwa, „Prokuratura i Prawo” 1997, nr 2, s. 8-14.

${ }^{26}$ Art. 15a wprowadzony do u.z.n.k. ustawą nowelizującą z 9 września 2000 r., Dz. U. Nr 93, poz. 1027.

${ }^{27}$ Por. M. Szwarczyk, w: T. Bojarski (red.), Kodeks karny. Komentarz, wyd. 4, Warszawa 2011, s. 539.

${ }^{28}$ Ustawa z 22 stycznia 2000 r. o ratyfikacji Konwencji o zwalczaniu przekupstwa zagranicznych funkcjonariuszy publicznych w międzynarodowych transakcjach handlowych, Dz. U. Nr 15, poz. 178.

${ }^{29}$ Por. Uzasadnienie rządowego projektu ustawy o zmianie ustawy - Kodeks karny, ustawy - Kodeks postępowania karnego, ustawy o zwalczaniu nieuczciwej konkurencji, ustawy o zamówieniach publicznych oraz ustawy - Prawo bankowe (druk sejmowy nr 1718, s. 23-24 Uzasadnienia).

${ }^{30}$ Ustawa z 28 października 2002 r. o odpowiedzialności podmiotów zbiorowych za czyny zabronione pod groźbą kary, Dz. U. Nr 197, poz. 1661 ze zm.
} 
określone w art. 229 k.k. Natomiast podstawą odpowiedzialności cywilnej szeroko pojętego przedsiębiorcy za czyn nieuczciwej konkurencji polegający na przekupstwie osoby pełniącej funkcję publiczną pozostaje art. 15 a u.z.n.k. ${ }^{31} \mathrm{Na}$ marginesie warto także dodać, że w czasie prac nad u.z.n.k., w marcu 1992 r., Rada Legislacyjna wysunęła propozycję posłużenia się przez u.z.n.k. pojęciem ,,podmiot gospodarczy”. W uzasadnieniu wskazano, że art. 2 u.z.n.k. w projektowanej (i ostatecznie przyjętej) wersji ,,przeciwstawia działalność zarobkową działalności zawodowej, co może prowadzić do wniosku, że możliwe jest uczestniczenie w obrocie gospodarczym bez osiągania korzyści ${ }^{32}$.

Należy przy tym zauważyć, że art. 15a u.z.n.k. nie ogranicza zakresu odesłania do $\S 1$ art. 229 k.k. Stanowi on jedynie, że wskazanym w nim czynem nieuczciwej konkurencji, polegającym na przekupstwie osoby pełniącej funkcję publiczna, jest zachowanie osoby fizycznej określone w art. 229 k.k. Odwołanie się do „zachowania” mogłoby sugerować, iż ustawodawcy w przepisie tym chodziło jedynie o czynność sprawczą występku przekupstwa (o udzielenie albo obietnicę udzielenia korzyści majątkowej lub osobistej osobie pełniącej funkcję publiczna). W tym kontekście niejasnym pozostaje jednak, czy przy ustalaniu zakresu art. 15a u.z.n.k. należy uwzględniać chociażby okoliczność rzutująca na bezkarność sprawcy przestępstwa, o której mowa w $§ 6$ art. 229 k.k. Ten ostatni przepis zaś przewiduje rezygnację z ukarania sprawcy przestępstwa przekupstwa w sytuacji, gdy korzyść majątkowa lub osobista albo ich obietnica zostały przyjęte przez osobę pełniąca funkcję publiczną, a sprawca zawiadomił o tym fakcie organ powołany do ścigania przestępstw i ujawnił wszystkie istotne okoliczności przestępstwa, zanim organ ten o nim się dowiedział. Wobec wyraźnego odesłania do art. 229 k.k. (w całej rozciąłłości) można uznać, że w ramach art. 15a ustawy należy uwzględnić również i takie zachowanie, jakie następuje po udzieleniu korzyści i sprowadza się do poinformowania właściwego organu o fakcie wcześniejszego wręczenia korzyści (bądź obietnicy jej udzielenia) ${ }^{33}$.

Odrębnym pytaniem pozostaje kwestia o ewentualny wpływ bezkarności sprawcy na opis deliktu cywilnoprawnego. Przypomnieć bowiem wypada, że art. 3 u.z.n.k., określający sposób rozumienia czynu nieuczciwej konkurencji na gruncie tej ustawy, nie ogranicza się jedynie do wymogu sprzeczności zachowania z przepisami prawa, ale pozwala on także na zakwalifikowanie zachowania jako takiego czynu w wypadku, gdy pozostawało ono sprzeczne chociażby tylko z dobrymi obyczajami ${ }^{34}$. Tym samym stwierdzenie, że zachodza podstawy uzasadniające bezkarność, o których mowa w $\S 6$ art. 229 k.k., nie muszą przekładać się na zakres odpowiedzialności cywilnej, wobec czego nie

${ }^{31}$ Pojęcie ,,przedsiębiorcy” zostało zdefiniowane w art. 2 u.z.n.k. i w jej w rozumieniu pojęcie to obejmuje: ,osoby fizyczne, osoby prawne oraz jednostki organizacyjne nie mające osobowości prawnej, które prowadząc, chociażby ubocznie, działalność zarobkową lub zawodową uczestniczą w działalności gospodarczej".

${ }^{32}$ T. M. Knypl, op. cit., s. 99.

${ }_{33}$ Por. M. Mozgawa, w: J. Szwaja (red.), op. cit., s. 608-609.

${ }^{34}$ W kwestii ,dobrych obyczajów” por. wyrok Sądu Apelacyjnego w Lublinie z 30 września 1998 r., sygn. akt I ACa 281/98, Lex, nr 35787, a także: M. Kępiński, op. cit., s. 7. 
można wykluczyć, że sprawca korzystający z wyrażonej w tym przepisie klauzuli bezkarności nie poniesie odpowiedzialności za czyn nieuczciwej konkurencji. Powyższe dowodzi jednak, że redakcję art. 15a u.z.n.k. i zawarte w niej nieprecyzyjne odesłanie do przepisu karnego należy uznać za rozwiązanie niefortunne. Dodatkowe problemy w tym względzie może zaś stwarzać fakt, że opisane w nim zachowanie nie tylko ,czerpie” w swojej istocie z opisu typu czynu zabronionego uregulowanego w art. 229 k.k., ale nadto - jako że stanowi ono czyn nieuczciwej konkurencji (art. 15a określa delikt cywilnoprawny) wymaga zgodności opisu zachowania z art. 3 u.z.n.k., definiujaccym taki czyn ${ }^{35}$.

Przytoczone problemy związane $\mathrm{z}$ wyznaczeniem wspólnej płaszczyzny przepisów cywilnych i karnych ustawy o zwalczaniu nieuczciwej konkurencji uzasadniają przekonanie, że zasadne będzie opowiedzenie się za wzajemną niezależnością zawartych w niej regulacji cywilnej i karnej w zakresie, w jakim zachowanie sprawcy czynu zabronionego nie musi odpowiadać opisowi „odpowiadającego” mu czynu nieuczciwej konkurencji. Zaakceptować można natomiast pogląd, że wskazana będzie taka interpretacja znamion typów czynów zabronionych, która prowadzi do nadania im znaczenia odpowiadającego temu, jakie nadają mu normy zawarte w opisie deliktów nieuczciwej konkurencji ${ }^{36}$. Przykładem tego może być art. 11 ust. 4 u.z.n.k., w którym zostało zdefiniowane pojęcie tajemnicy przedsiębiorstwa, które z kolei w opisie znamion uwzględnia także występek unormowany w art. 23 u.z.n.k. Zastrzec jednak wypada, że nie wydaje się uprawnione ograniczanie stosowania przepisów karnych wyłącznie do sytuacji, gdy ,,pozwoli” na to uprzednio dokonana subsumcja danego zachowania pod konkretny przepis cywilny, w którym został uregulowany delikt cywilnoprawny. Przyjęcie przeciwnego stanowiska prowadziłoby bowiem do wielu trudności, w szczególności związanych z wyznaczeniem obszaru regulacji prawnokarnych i nadania im nieznajdującego logicznego uzasadnienia - charakteru ,„wtórnego” względem przepisów cywilnych.

Wskazać należy również, że wobec braku wyłączenia stosowania Kodeksu karnego, jego przepisy i określone w nich instytucje prawa karnego znajduja zastosowanie w pełnej rozciagłości do ustawy z 16 kwietnia $1993 \mathrm{r}$. Wniosek taki wypływa z art. 116 k.k., zgodnie z którym przepisy części ogólnej Kodeksu stosuje się do innych ustaw przewidujących odpowiedzialność karną, chyba że ustawy te wyraźnie wyłączają ich zastosowanie. Podobnie materię tę reguluje art. 46 Kodeksu wykroczeń, który znajduje zastosowanie do wykroczeń, o których mowa w art. 25 i 26 u.z.n.k. (nieoznaczenie lub wprowadzające w błąd oznaczenie towarów oraz rozpowszechnianie nieprawdziwych lub wprowadzających w błąd wiadomości o przedsiębiorstwie). Z tego wynika, że występki

${ }^{35}$ Por. M. Sieradzka, w: eadem, M. Zdyb (red.), op. cit., s. 548.

${ }^{36}$ Por. J. Raglewski, który z jednej strony uważa, że: ,[...] ustalanie jurydycznego znaczenia poszczególnych znamion typów czynów karalnych winno odbywać się poprzez pryzmat opisów czynów nieuczciwej konkurencji”, z drugiej jednak zastrzega, iż: „Istotne znaczenie mają jednak różnice wynikające $\mathrm{z}$ tego, że niekiedy ujęcie znamion typu czynu karalnego jest szersze od stanowiącego jego odpowiednik tzw. nazwanego czynu nieuczciwej konkurencji”, idem, w: M. Sieradzka, M. Zdyb (red.), op. cit., s. $826-827$. 
uregulowane w art. 23-24a) wspomnianej ustawy powinny być objęte pięcioletnim okresem przedawnienia karalności. Zgodnie z art. $101 \S 1$ pkt 4 k.k., karalność występków zagrożonych karą pozbawienia wolności nieprzekraczająca 3 lat ustaje bowiem $\mathrm{z}$ upływem takiego okresu. W przypadku występków zagrożonych karą pozbawienia wolności przekraczająca 5 lat termin przedawnienia wynosi 15 lat (art. $101 \S 1$ pkt 2a k.k.) ${ }^{37}$. W świetle przepisów karnych ustawy z 16 kwietnia 1993 r., czyny zabronione określone w art. 23-24 stanowią występki, dla których przewidziano zagrożenie karą pozbawienia wolności nieprzekraczająca 2 lat. Czyn zabroniony spenalizowany w art. 24a tej ustawy zagrożony jest karą pozbawienia wolności od 6 miesięcy do 8 lat.

Niezależnie od powyższego, ustawa o zwalczaniu nieuczciwej konkurencji w art. 20 wskazuje również na odrębny, trzyletni okres przedawnienia roszczeń wynikających z popełnienia czynu nieuczciwej konkurencji. Sytuacja taka nie budziłaby wątpliwości, skoro - co do zasady - nie ma przeszkód, aby okres przedawnienia czynów karalnych (a więc okres przedawnienia karalności wynikający ze stosowania k.k.) był dłuższy niż okres przedawnienia roszczeń wynikający z przepisów cywilnych. Tym samym ochrona prawnokarna jest dłuższa, aniżeli ta zapewniana normami cywilnoprawnymi.

Pojawia się jednak problem, jeżeli sięgnąć do art. 20 u.z.n.k. Przepis ten $\mathrm{w}$ zakresie dochodzenia roszczeń wynikających $\mathrm{z}$ popełnienia czynu nieuczciwej konkurencji przewiduje odesłanie do art. 442 k.c. Ten ostatni zaś został uchylony nowelą do Kodeksu cywilnego z 16 lutego 2007 r. $^{38}$ Przepisy ustawy o zwalczaniu nieuczciwej konkurencji, pomimo że jeszcze w 2007 r. zostały poddane pewnym zmianom, to jednak nie dotyczyły one art. 20 tej ustawy. W dalszym ciagu zatem artykuł ten odsyła do art. 442 k.c. W Kodeksie cywilnym natomiast powołana nowelizacja z 16 lutego $2007 \mathrm{r}$., po uchyleniu art. 442, wprowadzono art. $442^{1}$ uprawniajacy do dochodzenia roszczenia o naprawienie szkody wyrządzonej czynem niedozwolonym i ustanawiający trzyletni okres przedawnienia takiego roszczenia. W $\S 2$ tego artykułu stanowi się jednak, że: „Jeżeli szkoda wynikła ze zbrodni lub występku, roszczenie o naprawienie szkody ulega przedawnieniu $\mathrm{z}$ upływem lat dwudziestu od dnia popełnienia przestępstwa bez względu na to, kiedy poszkodowany dowiedział się o szkodzie i o osobie obowiązanej do jej naprawienia”. Powyższe może powodować pewne komplikacje związane: po pierwsze, z ustaleniem czy uprawnionym będzie stosowanie art. $442^{1}$ k.c. pomimo wyraźnego odesłania w art. 20 u.z.n.k. do jego ,,poprzednika” (art. 442 k.c.), a po wtóre, ze zbiegiem okresów przedawnienia wynikających z art. 20 tej ustawy, $\mathrm{z}$ art. $442^{1} \S 2$ k.c. i dodatkowo art. $101 \S 1$ k.k.

W odpowiedzi na pierwszą z podniesionych wątpliwości, wskazać należy, że zgodnie z przepisem przejściowym wyrażonym w art. 2 ustawy nowelizującej Kodeks cywilny, do roszczeń o naprawienie szkody wyrządzonej czynem niedozwolonym, powstałych przed dniem jej wejścia w życie (10 sierpnia 2007 r.), a w tym dniu nieprzedawnionych jeszcze według przepisów dotychczasowych,

${ }^{37}$ Podobnie: M. Mozgawa, w: J. Szwaja (red.), op. cit., s. 965.

${ }^{38}$ Por. art. 1 ustawy z 16 lutego 2007 r. o zmianie ustawy - Kodeks cywilny, Dz. U. Nr 80, poz. 538. 
stosuje się przepisy art. $442^{1}$ k.c. ${ }^{39}$ Tym samym w konkretnym przypadku, w którym mielibyśmy do czynienia z takim roszczeniem, nie byłoby przeszkód do stosowania na ogólnych zasadach przepisów Kodeksu cywilnego, w tym w szczególności art. $442^{1}$ k.c. Powołanie się na ten przepis należałoby jednak wyinterpretować z ogólnych założeń prawa cywilnego, a nie stosować go z racji odesłania zawartego $\mathrm{w}$ art. 20 ustawy, skoro ten ostatni wskazuje na uchylony art. 442 k.c.

Nieco bardziej złożona wydaje się kwestia zbiegu terminów przedawnienia wynikających z k.k. i art. $442^{1} \S 2$ k.c. W tym wypadku konieczne będzie ustalenie, czy mamy do czynienia z okresem przedawnienia roszczeń cywilnoprawnych (roszczenia o naprawienie szkody wyrządzonej czynem niedozwolonym), czy przedawnienia karalności czynów zabronionych. W odniesieniu do roszczeń cywilnoprawnych podstawowym terminem ich przedawnienia będzie okres trzyletni, ustanowiony na mocy art. 20 u.z.n.k. Gdyby jednak podstawa dochodzenia takiego roszczenia była szkoda wynikająca z popełnienia przestępstwa, właściwe będzie zastosowanie ,wydłużonego” terminu przedawnienia, czyli przewidzianego $\mathrm{w}$ art. $442^{1} \S 2$ k.c. ${ }^{40}$ Taki okres przedawnienia biegnie dla przedsiębiorcy bądź innego podmiotu uprawnionego do jego dochodzenia. Natomiast odrębną kwestią pozostaje fakt, że w zależności od tego, o jaki występek określony w omawianej ustawie z 16 kwietnia 1993 r. będzie chodziło, po upływie, odpowiednio, 5 bądź 15 lat nie będzie podstaw do wszczęcia postępowania karnego w sprawie o popełnienie takiego występku, a wszczęte będzie należało umorzyćc ${ }^{41}$.

Kolejną, pojawiająca się na zbiegu przepisów cywilnych i karnych ustawy o zwalczaniu nieuczciwej konkurencji kwestią jest problematyka dotycząca szkody. W pierwszym rzędzie warto przypomnieć, że wszystkie czyny nieuczciwej konkurencji polegaja na takim działaniu (sprzecznym z prawem lub dobrymi obyczajami), które narusza albo chociażby tylko zagraża interesowi przedsiębiorcy (art. 3 ustawy). Na konieczność wystapienia takiego zagrożenia albo naruszenia wskazuje dodatkowo również art. 11 ust. 1 ustawy, określający czyn nieuczciwej konkurencji polegający na bezprawnym ujawnieniu tajemnicy przedsiębiorstwa ${ }^{42}$. Słusznie przy tym zauważano, że każde naruszenie tajemnicy, jaką objęta jest cudza informacja, jeśli tylko wpływa negatywnie na pozycję gospodarczą danego podmiotu, może stanowić delikt nieuczciwej konkurencji ${ }^{43}$.

Artykuły 23 (regulujacy odpowiadający temu deliktowi występek) oraz 24 u.z.n.k. (penalizujący niedozwolone kopiowanie produktu) stawiaja dalej idące wymagania do realizacji znamion typów czynów zabronionych w nich określonych. Uzależniają one popełnienie przestępstwa od nastąpienia skutku w postaci powstania ,,poważnej szkody”. Jak słusznie zwrócił na to uwagę Sąd

${ }^{39}$ Ustawa z 16 lutego 2007 r. o zmianie ustawy - Kodeks cywilny, Dz. U. Nr 80, poz. 538.

${ }^{40}$ Podobnie: J. Szwaja, w: idem (red.), op. cit., s. 947-953.

41 Por. art. $17 \S 1$ pkt 6 k.p.k.

${ }^{42}$ Por. J. Szwaja, Ostatnie nowelizacje ustawy o nieuczciwej konkurencji. Cz. I, „Monitor Prawniczy" 2002, nr 24, s. 1115.

${ }^{43}$ E. Nowińska, M. du Vall, op. cit., s. 178. 
Najwyższy w wyroku z 3 kwietnia 2002 r.: ,Sformułowanie »... jeżeli wyrządza to poważną szkodę przedsiębiorcy « [...] nie określa tzw. obiektywnego warunku karalności, ale konstytutywny dla bytu czynu zabronionego skutek przestępny" ${ }^{44}$, co powoduje, że możliwe jest popełnienie tych przestępstw również $\mathrm{w}$ formie usiłowania. Natomiast nie sposób byłoby uznać, że wystąpienie szkody innej niż - verba legis - „poważna” uzasadnia potraktowanie zachowania sprawcy jako karalnego usiłowania. Zgodnie z art. 13 § 1 k.k. usiłowaniem będzie bowiem każde zamierzone zachowanie, które będzie zmierzało bezpośrednio do wywołania takiego skutku (szkody, którą należałoby uznać za poważną).

Na wybitnie ocenny charakter znamienia odnoszącego się do ,ppoważnej” szkody wskazywano już w piśmiennictwie ${ }^{45}$. Doprowadziło to do wypracowania w orzecznictwie i doktrynie kilku metod prowadzących do jego uściślenia. Najczęściej odwoływano się do metody proporcjonalnej, według której o tym, czy szkodę należało uznawać za ,poważną”, decydował wskaźnik procentowy (stosunkowy) obliczany według udziału doznanego uszczerbku w mieniu bądź metody wielkości absolutnej, dla której istotne znaczenie miała wartość wyrażona w liczbach bezwzględnych uzasadniająca zaliczenie szkody do „,poważnej”, względnie opierano się na metodzie mieszanej, stanowiącej połączenie elementów dwóch wyżej wspomnianych kryteriów ${ }^{46}$.

$\mathrm{W}$ pierwotnym brzmieniu u.z.n.k., normując w art. 25 ust. 1 wykroczenie wprowadzającego w błąd oznaczenia albo nieoznaczenia towarów, wymagała do jego popełnienia skutku $\mathrm{w}$ postaci spowodowania ,istotnej szkody" ${ }^{47}$. Jak trafnie przy tym zaznaczono, określenia ,istotna” i ,,poważna” (które z czysto językowego punktu widzenia uchodzą za wyrazy bliskoznaczne), na gruncie ustawy miały inny wymiar, bowiem ,szkoda istotna była innej jakości niż szkoda poważna, inny był układ ustawowych znamion, inny przedmiot ochrony" ${ }^{48}$. Podzielając powyższe stanowisko, należy opowiedzieć się z całą stanowczością za poglądem, według którego ,,[...] należy uwzględniać kryterium proporcjonalności zaistniałej szkody do rozmiarów działalności gospodarczej prowadzonej przez przedsiębiorcę, którego tajemnica została naruszona zachowaniem sprawcy. Zaistniała szkoda musi być bowiem poważna dla konkretnego podmiotu, a nie w ujęciu abstrakcyjnym" ${ }^{49}$.

$\mathrm{Na}$ gruncie zbiegu przepisów cywilnych i karnych u.z.n.k. interesująca wydaje się również kwestia samego pojęcia ,szkody”. Prawnocywilny aspekt jej ujmowania prowadzi do wniosku, że szkodą może być zarówno uszczerbek majątkowy, jak i niemajątkowy (niematerialny; utożsamiany $\mathrm{w}$ prawie

\footnotetext{
${ }^{44}$ Wyrok Sądu Najwyższego z 3 kwietnia 2002 r., sygn. akt V KKN 223/2000, „Orzecznictwo Sądu Najwyższego - Izba Karna i Wojskowa” 2002, z. 7-8, poz. 65.

${ }^{45}$ Por. J. Raglewski, op. cit., s. 130-131.

${ }^{46}$ Por. P. Kozłowska-Kalisz, Odpowiedzialność karna za naruszenie tajemnicy przedsiębiorstwa, Kraków 2006, s. 247-250.

${ }^{47}$ Nowelizacją do u.z.n.k. z 5 lipca 2002 r. uchylono znamię ,istotna” odnoszące się do szkody, Dz. U. Nr 126, poz. 1071.

${ }^{48}$ Por. P. Kozłowska-Kalisz, op. cit., s. 257.

49 J. Raglewski, w: M. Sieradzka, M. Zdyb (red.), op. cit., s. 856.
} 
cywilnym $\mathrm{z}$ reguły $\mathrm{z}$ krzywdą $)^{50}$. Postulat takiego pojmowania szkody również na gruncie prawa karnego wyrażono $\mathrm{w}$ piśmiennictwie prawnokarnym ${ }^{51}$. Za takim podejściem do problematyki szkody wyrządzonej w związku z prowadzeniem działalności gospodarczej opowiedział się Sąd Najwyższy, uznając w jednym ze swoich wyroków, że: „Agresywne i nieuczciwe działanie o charakterze marketingowym mogą być uznane za czyn niedozwolony" ${ }^{2}$. Z kolei ograniczenie szkody do jej majątkowego aspektu wymagałoby nadania temu znamieniu takiego znaczenia, jakie szkoda majątkowa ma w prawie cywilnym $^{53}$. Wobec tego należałoby przez nią rozumieć: ,[...] zarówno uszczerbek $\mathrm{w}$ majątku, obejmujący rzeczywistą stratę (damnum emergens), polegająca na zmniejszeniu się aktywów majątku przez ubytek, utratę lub zniszczenie jego poszczególnych składników albo na zwiększeniu się pasywów, jak i utracony zysk (lucrum cessans), wyrażający się w udaremnieniu powiększania się majątku" 54. Innymi słowy, szkodę majątkową stanowi różnica między stanem majątkowym poszkodowanego istniejącym po doznanym uszczerbku a stanem, jaki by istniał, gdyby nie nastąpiło zdarzenie wywołujące szkodę ${ }^{55}$. Na taki sposób interpretowania tego znamienia mogłaby wskazywać chociażby wykładnia systemowa dokonana w oparciu o całokształt przepisów karnych (w tym zwłaszcza uwzględniająca uregulowania zawarte w Kodeksie karnym $^{56}$ ), tudzież odwołująca się do poglądów wyrażonych na ich podstawie przez doktrynę prawa karnego ${ }^{57}$ i judykaturę ${ }^{58}$. Z drugiej strony jednak nie sposób nie dostrzec, iż ustawodawca nie posługuje się w art. 23 i 24 u.z.n.k. żadnym doprecyzowaniem, które uprawniałoby do zaprezentowanej powyżej interpretacji. Nie odwołuje się on przecież do wyraźnego wskazania, że

${ }^{50}$ Por. T. Wiśniewski, w: G. Bieniek (red.), Komentarz do kodeksu cywilnego. Ksiega trzecia. Zobowiazania, t. 1, Warszawa 2011, s. 80-82, a także: J. Kaspryszyn, Roszczenie z art. 439 k.c. a inne instytucje ochrony prewencyjnej. Próba określenia wzajemnych relacji, „Palestra” 1999, z. 9-10, s. 12-13.

${ }^{51}$ R. Kaczmarek, Pojęcie szkody $w$ literaturze karnistycznej $w$ porównaniu z cywilnoprawna jej kwalifikacja, „Nowe Prawo” 1982, z. 11-12, s. 63-68, a także: J. Giezek, P. Kardas, w: S. Sołtysiński, A. Szajkowski, A. Szumański, J. Szwaja (red.), Kodeks spółek handlowych. Komentarz, t. V [komentarz do art. 585 k.s.h.], Warszawa 2004, s. 25.

${ }^{52}$ Wyrok Sądu Najwyższego z 17 czerwca 2003 r., sygn. akt III CKN 1362/2000, niepubl.

${ }^{53}$ Por. J. Olszewski, Nieuczciwa konkurencja, Warszawa 1995, s. 106-107, a także: P. Kardas, Szkoda majatkowa jako znamie przestępstwa nadużycia zaufania, „Prokuratura i Prawo” 1994, z. 7-8, s. $36-55$.

${ }^{54}$ Uchwała Sądu Najwyższego z 21 czerwca 1995 r., sygn. akt I KZP 22/95, „Orzecznictwo Sądu Najwyższego - Izba Karna i Wojskowa” 1995, z. 9-10, poz. 58, podobnie: wyrok Sądu Apelacyjnego w Krakowie z 20 kwietnia 2000 r., II AKa 32/2000, „Krakowskie Zeszyty Sądowe” 2000, z. 6, poz. 15, 16, 22 i 26.

55 Orzeczenie Sądu Najwyższego z 11 lipca 1957 r., sygn. akt 2 CR 304/57, OSNPG 1958, z. 10, s. 23.

56 Por. W. Kubala, Pojęcie szkody w kodeksie karnym, „Państwo i Prawo” 1975, z. 5, s. 74-77 i 82-84.

${ }^{57}$ Za takim sposobem rozumienia szkody także na gruncie przepisów karnych u.z.n.k. opowiedział się M. Mozgawa, Zwalczanie nieuczciwej..., s. 40-41; idem, Przestęstwa stypizowane w ustawie o nieuczciwej konkurencji, ,Monitor Prawniczy” 1994, nr 4, s. 102.

${ }^{58}$ Por. wyrok Sądu Okręgowego w Tarnowie z 19 lutego 2004 r., sygn. akt II Ka 30/2004, „Krakowskie Zeszyty Sądowe” 2004, z. 3, poz. 37; R. Horbaczewski, Szkoda musi być konkretna, „Rzeczpospolita” 2009, nr 87, s. C3 i powołany tam wyrok Sądu Okręgowego w Zamościu z 2009 r., sygn. akt I C 418/2009, a także: uchwała Sądu Najwyższego Izba Karna z 22 stycznia 1992 r., sygn. akt I KZP 37/91, „Orzecznictwo Sądu Najwyższego - Izba Karna i Wojskowa” 1992, z. 5-6, poz. 38, w której Sąd ten wyraźnie wiąże pojęcie szkody (majątkowej) z odszkodowaniem, zadośćuczynienie zaś z krzywdą, rozumianą jako szkoda niemajątkowa. 
$\mathrm{w}$ przestępstwach określonych $\mathrm{w}$ tych przepisach skutek ma polegać na wywołaniu szkody majątkowej (materialnej). Co więcej, wykładnia teleologiczna prowadzi do wniosku, że interesy przedsiębiorcy albo innego uczestnika obrotu gospodarczego podlegające ochronie prawnokarnej obejmuja nie tylko czerpane przez niego dochody, względnie utracone zyski, ale również jego pozycję rynkową ${ }^{59}$. Ta ostatnia zaś, wiąże się $\mathrm{z}$ rozpoznawalnością firmy (marką), wobec czego wymaga ona uwzględnienia szeroko pojętych interesów, w tym także niemajątkowych.

Na zakończenie warto wreszcie podnieść jeszcze jeden problem, jaki wyłania się na gruncie zbiegu norm prawa cywilnego i karnego zawartych w u.z.n.k. Dotyczy on zachowania sprawcy, które - gdyby przyjąc, że winno ono stanowić czyn nieuczciwej konkurencji - ograniczałoby się tylko do jednej jego formy, a mianowicie: działania ${ }^{60}$. To natomiast pozostawałoby $w$ sprzeczności $\mathrm{z}$ utrwalonym w prawie karnym sposobem postrzegania czynu jako zachowania, które może wyrażać się tak w działaniu (aktywności, kompleksie ruchów), jak i zaniechaniu (braku aktywności w spodziewanym kierunku; braku kompleksu ruchów ${ }^{61}$. Kwestia jest tym bardziej doniosła, że niektóre z czynów zabronionych określonych $\mathrm{w}$ u.z.n.k. moga zostać popełnione również przez zaniechanie. Wystarczy wskazać na występek bezprawnego ujawnienia tajemnicy przedsiębiorstwa (art. 23 ust. 1) albo wykroczenie polegajace na nieoznaczeniu wbrew obowiązkowi towarów albo usług (art. 25 ust. 1) ${ }^{62}$. W tej mierze pożądane, jak się zdaje, byłoby doprecyzowanie art. 3 u.z.n.k. przez wskazanie w tym przepisie na szeroko pojęte ,zachowanie”. Pozwoliłoby to na usunięcie wątpliwości związanych $\mathrm{z}$ prawnokarnym sposobem interpretacji tego przepisu ${ }^{63}$.

Reasumując, powołane powyżej przepisy cywilne i karne zawarte w u.z.n.k. dowodzą niezbicie, że na płaszczyźnie zazębiających się regulacji dochodzi do pewnych nieścisłości. W dużej mierze są one wynikiem odrębności, jakie w systemie prawa spełniają obydwie gałęzie prawa. Bezspornym pozostaje przy tym, że w myśl zasady ultima ratio ochrona wynikająca ze stosowania środków reakcji prawnokarnej winna znaleźć zastosowanie dopiero wówczas, gdy inne mechanizmy służące zapewnieniu uczciwej konkurencji okażą się niewystarczające $^{64}$. Równocześnie jednak autonomiczna wykładnia przepisów karnych i powinność nadawania im jednoznacznego, kompletnego i niepozostawiającego wątpliwości charakteru prowadzi do wniosku ${ }^{65}$, że nie byłoby

\footnotetext{
${ }^{59}$ Por. E. Nowińska, M. du Vall, op. cit., s. 402-404; L. Górnicki, op. cit., s. 122. Więcej na ten temat także: P. Kozłowska-Kalisz, op. cit., s. 256-268.

${ }^{60}$ Art. 3 u.z.n.k. za czyn nieuczciwej konkurencji uznaje tylko działanie (sprzeczne z prawem lub dobrymi obyczajami).

${ }^{61}$ Por. A. Marek, Prawo karne, wyd. 10, Warszawa 2011, s. 95; a także: K. Buchała, A. Zoll, Polskie prawo karne, wyd. 2, Warszawa 1997, s. 115-118.

${ }^{62}$ Por. J. Raglewski, w: M. Sieradzka, M. Zdyb (red.), op. cit., s. 842-843 i 899; podobnie: M. Mozgawa, Zwalczanie nieuczciwej..., s. 59.

${ }^{63} \mathrm{~W}$ literaturze cywilnoprawnej ,upraszcza się" nieco ten problem, uznając, że działanie obejmuje także zaniechanie - por. M. Zdyb, w: M. Sieradzka, M. Zdyb (red.), op. cit., s. 98; podobnie: J. Szwaja, w: idem (red.), op. cit., s. 141.

${ }^{64}$ K. Buchała, A. Zoll, op. cit., s. 127; a także: J. Skorupka, op. cit., s. 23.

${ }^{65}$ W kwestii wykładni autonomicznej por. R. Zawłocki, op. cit., s. 17, a zasady określoności: art. 42 Konstytucji RP oraz P. Winczorek, op. cit., s. 62. Przed wejściem w życie Konstytucji z 1997 r. za takim
} 
poprawne ograniczanie czynów karalnych określonych w art. 23-26 u.z.n.k. do zachowań stanowiących „odpowiadające im” czyny nieuczciwej konkurencji ${ }^{66}$. W przypadku u.z.n.k. postulat taki zdaje się tym bardziej zasługiwać na uwagę, że przepisy rzeczonej ustawy mają za zadanie chronić zarówno podmioty występujące $\mathrm{w}$ obrocie gospodarczym, jak i szeroko pojęty interes publiczny. Niezależnie od roli, jaka $\mathrm{w}$ tym zadaniu przypadnie regulacjom cywilnym, a jaka karnym, to wypada zauważyć, że jedne i drugie wprowadzają właściwe sobie sposoby sankcjonowania zachowań niedozwolonych w obrocie gospodarczym $^{67}$. Ich celem jest zwalczanie takich zachowań, które sprawiałyby, że przedsiębiorca rozwijałby swą działalność i zdobywał miejsce na rynku kosztem konkurencji i przy naruszaniu jej prawnie chronionych interesów. W tym zakresie właściwe byłoby zatem wprowadzenie na tyle spójnych regulacji cywilnych i karnych, aby nie powstawały wątpliwości związane z ich wykładnią, czemu służyłoby unormowanie ich w analogiczny sposób w każdym możliwym i znajdującym uzasadnienie wypadku.

dr Anna Golonka

Uniwersytet Rzeszowski

\title{
THE ACT ON COMBATING UNFAIR COMPETITION: DELIBERATIONS VIS A VIS THE CONCURRENCE OF CIVIL AND CRIMINAL LAW
}

\author{
Summary
}

\begin{abstract}
The Act on Combating Unfair Competition defines prohibited behaviours which the Act refers to as unfair competition acts, and which are, as a matter of fact, delicts (torts). A typification of such behaviours constitutes the core provisions of the above mentioned regulation. Besides the civil law provisions, the Act provides for the strengthening of the protection of the economic market participants against unfair competition acts, including implementation of criminal norms to assits the achievement of the goal. Civil and penal provisions, despite regulating the same matter, include, however not only quite different legal solutions (which would be understandable taking into account the nature of both branches of law) but - what is more - they also define, albeit in different ways, the same prohibited behaviours. Just to take as an example unfair competition, such as the disclosure of trade secrets or illegal imitation of products, compared with the corresponding punishable acts. The discrepancies between the provisions of civil law and criminal law that are present in the Act under discussion call for an in-depth analysis of those issues. The conclusions consequently drawn from that discussion should idenify a direction of expected changes in the regulations and, consequently, eliminate the doubts that hamper their practical application.
\end{abstract}

sposobem formułowania przepisów karnych opowiedział się Trybunał Konstytucyjny w postanowieniu z 13 czerwca 1994 r., sygn. akt S. 1/94, „Orzecznictwo Trybunału Konstytucyjnego 1994”, t. I, poz. 28, s. 271 .

${ }^{66}$ Por. J. Raglewski, w: M. Sieradzka, M. Zdyb (red.), op. cit., s. 826-827; a także - na gruncie art. 24a u.z.n.k. - M. Mozgawa, w: J. Szwaja (red.), op. cit., s. 1004.

${ }^{67}$ Por. C. Kosikowski, T. Ławicki, Ochrona prawna konkurencji $i$ zwalczanie praktyk monopolistycznych, Warszawa 1994, s. 161. 